\title{
Deep water macroalgal communities adjacent to the Florida Keys reef tract
}

\author{
James J. Leichter ${ }^{1, *}$, M. Dale Stokes ${ }^{1}$, Salvatore J. Genovese ${ }^{2}$ \\ ${ }^{1}$ Scripps Institution of Oceanography, University of California at San Diego, 9500 Gilman Drive, La Jolla, \\ California 92093-0227, USA \\ ${ }^{2}$ Marine Science Center, Northeastern University, Nahant, Massachusetts 01908, USA
}

\begin{abstract}
A combination of remotely operated vehicle and SCUBA dives at 40 to $80 \mathrm{~m}$ depth seaward of the Florida Keys reef tract revealed extensive areas of the seafloor dominated by communities of large benthic macroalgae. Macroalgal cover exceeded $80 \%$ in many areas where the substratum was dominated by coral and shell fragments and calcareous cobbles. Macroalgal cover differed significantly among sites and depths. At 2 sites to the northeast, macroalgal cover was relatively low at $30 \mathrm{~m}$ depth close to the reef tract, increased to maximal densities at 50 to $60 \mathrm{~m}$, and then decreased at 70 to $80 \mathrm{~m}$. At 2 sites to the southwest, macroalgal cover ranged from 10 to $80 \%$ and was inversely related to the presence of deep shifting sands. The concentration of total inorganic nitrogen in the water column was closely associated with decreased temperature below approximately $26^{\circ} \mathrm{C}$. Bottom temperature records showed extensive variability and frequent periods of cooling indicative of short term upwelling, pointing to high nutrient availability and markedly increased duration and magnitude of cooling with increasing depth. Water column measurements of photosynthetically active radiation showed an average vertical light attenuation coefficient of $-0.056 \mathrm{~m}^{-1}( \pm 0.011 \mathrm{SE})$. Thus average light availability is expected to vary from approximately $16 \%$ of surface irradiance at $30 \mathrm{~m}$ to $<1 \%$ at $80 \mathrm{~m}$. A 9 mo algal recruitment experiment showed greatest recruitment in areas with high macroalgal cover, but algae did recruit to the artificial surfaces in areas with low adult cover except where shifting sand was abundant. Algal recruitment was low in close proximity to the reefs at $30 \mathrm{~m}$ depth. The observed patterns suggest high rates of benthic primary production in this environment and a potentially important role of drift algae and detritus transported onshore as a source of fixed carbon for reef-associated consumers.
\end{abstract}

KEY WORDS: Macroalgae $\cdot$ Florida Keys $\cdot$ Coral reefs $\cdot$ Light $\cdot$ Nutrients

\section{INTRODUCTION}

The importance of the ecosystems adjacent to coral reefs in shallow water is widely recognized. Specifically, both mangrove communities and seagrass beds can play important roles in mediating nutrient and sediment fluxes from land and can provide essential habitat for recruitment of invertebrates and fish, many of which subsequently inhabit nearby coral reefs as adults (Ellison \& Farnsworth 2001, Valiela et al. 2001, Williams \& Heck 2001, Mumby et al. 2004). Knowledge of ecological processes for communities in deeper water adjacent to coral reefs is much more limited. Yet the euphotic zone in relatively clear, tropical waters may extend to depths of 80 to $100 \mathrm{~m}$ or more. Thus, there is strong potential for significant primary production below the depths of most ecological studies on coral reefs as well as exchange of materials and individuals among deep and shallow ecosystems. Deep reefs are known as sites of fish spawning aggregations (Colin 1996, Domeier \& Colin 1997), and the population trajectory for coral populations at depths of greater than $30 \mathrm{~m}$ has been shown to be different from that of shallower zones (Bak et al. 2005). However, the logistical barriers to working at depths $>30-40$ m has contributed to a relative paucity of ecological studies on 
deep reefs and adjacent habitats. Here we focus on algal communities at depths of 30 to $80 \mathrm{~m}$ seaward of the Florida Keys Reef Tract (FLKRT). Although taxonomic descriptions of deep water benthic macroalgal communities exist for other regions of the Florida coast (Cheney \& Dyer 1974, Hanisak \& Blair 1988), the communities seaward of the FLKRT have received little previous attention. Very little is known about the ecological importance of deep algal communities in tropical systems in general.

Factors that regulate the abundance and distribution of macroalgae on shallow coral reefs (i.e. from the surface to approximately $25 \mathrm{~m}$ ) have been the focus of extensive past and present research. While considerable debate has focused on the relative importance of herbivory and nutrient effects as causes of algal blooms on coral reefs (e.g. Lapointe 1997, 1999, Hughes et al. 1999), both factors are clearly important in structuring algal communities at various times and locations (Hughes et al. 1999, Knowlton 2001, Smith et al. 2005). It has also been shown that algal dominance is not necessarily a simple measure of reef health or degradation and can reflect natural environmental variation (Vroom et al. 2006). The standing stock of macroalgal biomass is strongly controlled by herbivory in many instances (Carpenter 1986, Done 1992, Hughes et al. 1999, McCook 1999, Edmunds \& Carpenter 2001, Jompa \& McCook 2002). Additionally, growth rates of macroalgae and the overall condition of reef-associated algal communities can be strongly affected by the availability of macronutrients, especially inorganic nitrogen (Smith et al. 1981, Andrews \& Gentien 1982, Littler \& Littler 1984, Atkinson \& Bilger 1992, Bell 1992, Lapointe 1997, Leichter et al. 2003, Smith et al. 2005).

Herbivores capable of regulating algal abundance on Florida reefs include sea urchins, especially the long-spined urchin Diadema antillarum, as well as grazing fishes, particularly species within the families Acanthuridae (surgeonfishes), Pomacanthidae (angelfishes), Pomacentridae (damselfishes), and Scaridae (parrotfishes). These herbivores are generally found nearby or associated with reef primary structure, which likely provides a degree of cover from larger predators. The potential sources of inorganic nutrients in these systems include in situ fixation, fluxes out of reef matrices and sediments, terrestrial surface and groundwater runoff, atmospheric deposition, and localized upwelling of nutrient-rich subsurface waters (reviewed in D'Elia \& Wiebe 1990). The latter mechanism is known to be important along the FLKRT, where episodic but widespread input of nutrients is associated with the impact of internal waves occurring at tidal and faster frequencies (Leichter et al. 1996, 2003), and with upward excursions of the local thermocline associated with frontal eddies of the Florida Current (Lee \& Mayer 1977, Lee et al. 1985). Estimates of the fluxes of inorganic nutrients across the slope of Conch Reef in the Florida Keys suggest increases of more than an order of magnitude during internal wave events relative to non-internal wave periods (Leichter et al. 2003). Previous studies have shown that the common benthic macroalga Codium isthmocladum likely uses transiently available nitrate (Leichter et al. 2003, 2007). Further evidence of algal utilization of transient nutrient pulses at this site was provided by Smith et al. (2004) who showed increased growth rates and a decreased effect of artificial nutrient additions for the benthic alga Halimeda tuna with increasing depth from 7 to $21 \mathrm{~m}$. A complete nutrient budget for the FLKRT has not been developed, but high frequency upwelling appears to be a significant overall nutrient source for the outer reef slopes (Boyer \& Jones 2002, Kruczynski \& McManus 2002, Leichter et al. 2003).

In addition to increasing nutrient availability with depth, there is also an obvious attenuation of light with increasing depth. Thus, 2 of the major physical resources (nutrients and light) likely to govern productivity of benthic macroalgae exhibit opposing gradients with depth. In the Florida Keys and in Jamaica this dual gradient in resource availability has been implicated in a bimodal pattern of growth rates observed along a depth gradient for the scleractinian coral Madracis mirablilis which contains symbiotic microalgae (Leichter et al. 1998, Leichter \& Genovese 2006). It is likely that the limiting resource for specific algal taxa will vary along the depth gradient and that this variation may influence species diversity and algal production, especially in deeper waters.

In 2000 and 2001 we observed numerous large individuals of the green seaweeds Codium isthmocladum and $C$. decorticatum growing at 32 to $40 \mathrm{~m}$ depth just seaward of the bases of multiple sites along the FLKRT, as well as numerous rhodophyte (red algal) fragments and whole individuals being transported onshore in flows associated with individual internal tidal bores. This suggested there might be significant populations of large benthic macroalgae deeper and further offshore. Prior studies have reported abundant macroalgae growing at depths of 40 to $90 \mathrm{~m}$ offshore from the Florida coast near Ft. Lauderdale (Hanisak \& Blair 1988) as well as in the Florida Middle Grounds in the Eastern Gulf of Mexico (Cheney \& Dyer 1974). Algae at these intermediate depths may be nutrient replete due to transient nutrient upwelling (Hanisak \& Siemon 2000, Hanisak 2001). In temperate habitats the transport of macroalgae including kelp detrital fragments can be an important subsidy to secondary production in adjacent communities (Duggins et al. 1989, Bustamante et al. 1995, Vetter 1995, Graham et al. 2003). 
Algal production seaward of the FLKRT and subsequent onshore transport of fragments and detritus could be a similarly important source of organic material reaching reef associated consumers.

In this study we assessed the depth distributions and spatial extents of macroalgal communities at 30 to $80 \mathrm{~m}$ depth on the broad slope seaward of the FLKRT. Our goals were to examine overall distributions of macroalgae and patterns across broad taxonomic groups in this habitat, and to consider the importance of substratum type and frequency of short term upwelling events in structuring these communities. Specifically, we asked: (1) What is the distribution of macroalge in this system? (2) What is the depth-specific variability in bottom temperatures and relative nutrient availability and how does this compare with the depth distribution of photosynthetically active radiation (PAR)? (3) What is the role of substratum availability and type (grain size, cobble no/cobble) in macroalgal distributions, and if substratum is provided does algal recruitment follow? site we have recorded bottom temperature continually since 1996 at 10, 20, and 30 m depths. In this study, additional stations were established offshore from the fore reef stations on the 40,50,60 and $70 \mathrm{~m}$ isobaths, typically 0.5 to $2.0 \mathrm{~km}$ seaward of the reef. Sites were instrumented with temperature recorders as follows: high resolution $\left(0.001^{\circ} \mathrm{C}\right)$ Seabird SBE-39 temperature recorders sampling at $120 \mathrm{~s}$ intervals were deployed at 10,20, and $30 \mathrm{~m}$ depth on the reef slopes as well as $50 \mathrm{~m}$ seaward of the reef tract; lower resolution $\left(0.2^{\circ} \mathrm{C}\right)$ Onset Computers Waterpro temperature recorders sampling at $20 \mathrm{~min}$ intervals were deployed at the 30,40,50,60 and $70 \mathrm{~m}$ sites in conjunction with the algal recruitment study (see below) at EL and CR. CR has been the focus of intensive physical and biological study since the early 1990s.

The exposure to cool water was estimated for the EL and $\mathrm{CR}$ sites at 30 to $70 \mathrm{~m}$ depth by calculating the total degree hours per day $(D)$ below a chosen temperature threshold, $T_{\text {thresh }}$ :

$$
D=\sum\left(T_{\text {thresh }}-T_{\text {obs }}\right) \times 20 \mathrm{~min} / 60 \mathrm{~min}^{-1}
$$

\section{MATERIALS AND METHODS}

Study sites and benthic temperature. The FLKRT consists of a series of coral reefs broken by shallow channels, separated from shore by 5 to $8 \mathrm{~km}$ of water that ranges in depth from approximately 3 to $10 \mathrm{~m}$. Sessile benthic communities have moderate percent areal cover (ca. 10 to $50 \%$ ) and relatively high diversity (for the Caribbean and West Atlantic) of hard and soft corals, benthic algae, and sponges. Reef crests lie at 3 to $10 \mathrm{~m}$ depth, with fore reefs sloping to 30 to $35 \mathrm{~m}$ depth where they break into semi-isolated patches on sand. Seaward of the reef tract, the bottom slopes gradually, with depth increasing roughly 10 to $20 \mathrm{~m} \mathrm{~km}^{-1}$ offshore. Further offshore, the slope angle increases into the deep channel of the Florida Straits (depths of 800 to $1200 \mathrm{~m}$ at 70 to $100 \mathrm{~km}$ offshore). Surface tides are mixed-semidiurnal with mean amplitudes of 0.25 to $0.75 \mathrm{~m}$. The central axis of the Florida Current is typically located 10 to $40 \mathrm{~km}$ seaward of the reef tract, characterized by strong (ca. 0.5 to $1.5 \mathrm{~m} \mathrm{~s}^{-1}$ ) flows to the NE. Study sites for this work were established at Elbow Reef (EL), Conch Reef (CR), Looe Key Reef (LK), and Sand Key Reef (SK), spanning a linear distance of approximately 200 km (Fig. 1). At each
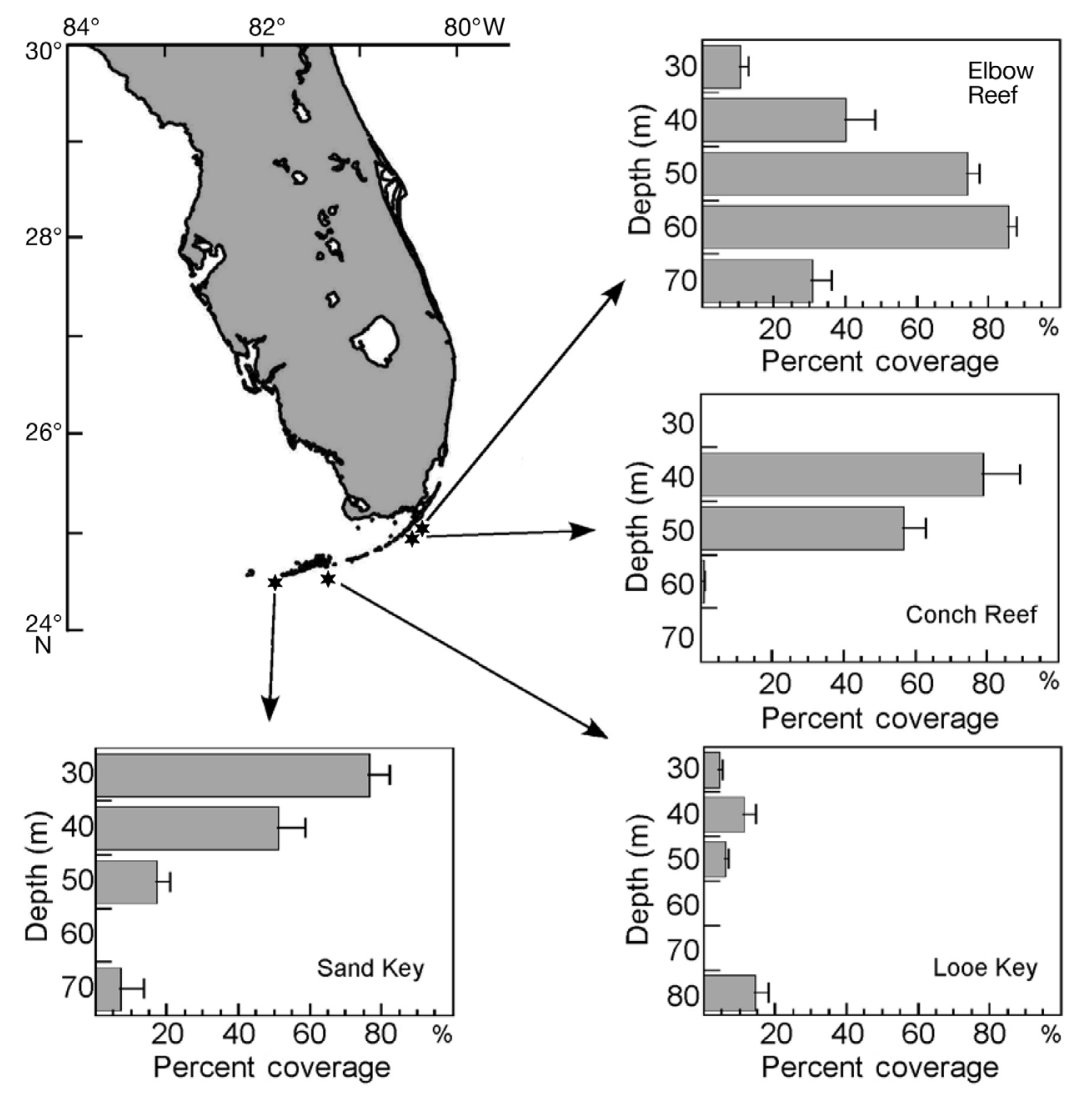

Fig. 1. Location of study sites on the seaward margin of the Florida Keys, USA. Panels show total algal percent cover as a function of depth, estimated from ROV bottom surveys in 2005. Area not covered by algae was predominantly covered by sand such that $100 \%$ - algal cover $\approx$ sand cover. Note that surveys were conducted to $80 \mathrm{~m}$ depth at all sites, but data are only shown where algae were found at that depth. Values are means + SE 
where $T_{\text {obs }}$ represents the temperature observed in each 20 min interval over the course of a day. This metric incorporates both the magnitude and duration of cooling events such that, for example, a cooling event of $2{ }^{\circ} \mathrm{C}$ below the threshold for $2 \mathrm{~h}$ would correspond to 4 cooling degree hours. Following the analysis of water column temperature-nutrient relationship (see below), $26^{\circ} \mathrm{C}$ was chosen as the threshold temperature below which total inorganic nitrogen (TIN) concentration increased in a nearly linear fashion with decreasing temperature. Total as well as mean and SD of the daily degree hours below $26^{\circ} \mathrm{C}$ were calculated for 30 to $70 \mathrm{~m}$ at EL and CR. To avoid a potential bias associated with winter-time cooling of the overall water column, the cool water exposure calculations were made using data from only the fall, spring, and early summer (September through October 2004, and May through June 2005) when the water column temperatures above the thermocline were typically 27 to $29^{\circ} \mathrm{C}$.

Nutrients and photon irradiance. Water column hydrographic, nutrient, and light sampling was conducted during cruises aboard the RV 'Walton Smith' in September 2002 and September 2003. At each of the study sites along the reef tract (EL, CR, LK, and SK) water sampling was conducted at distances of $0,0.9$, $1.8,3.7,5.6,7.4,9.3,11.1,14.8$, and $18.5 \mathrm{~km}$ offshore from the reef, with bottom depths ranging from 35 to $250 \mathrm{~m}$. A single hydrocast was made from the ship at each station using a Seabird 911+ conductivitytemperature-depth (CTD) meter with a fluorometer, Biospherical Instruments photosynthetically active radiation (PAR) sensor, and a water sampling rosette of ten 121 Niskin bottles.

Water samples were collected from 4 to 6 depths at each sampling station. Samples were taken at the maximum depth of each cast at regularly spaced intervals in the water column, and near the surface (3 $\mathrm{m}$ depth). Water samples were filtered immediately following the casts through $0.7 \mu \mathrm{m}$ pore size GF/F filters. Two $60 \mathrm{ml}$ filtered samples from each Niskin bottle were frozen for post-cruise determination of inorganic nutrient concentrations on an Alpkem autoanalyzer. TIN concentration for each sample was determined as the sum of nitrate, nitrite, and ammonium concentrations.

The hydrocast PAR sensor data was averaged in $1 \mathrm{~m}$ vertical bins using data collected from the downward portion of each cast. The light extinction coefficient $(k)$ in the PAR frequency band was calculated relative to PAR just below the surface for each cast from the relationship:

$$
I_{z}=I_{0} \times \mathrm{e}^{-k z}
$$

where $z$ represents depth, $I_{z}$ represents the light intensity at depth $z$ and $I_{0}$ represents light intensity just beneath the surface (Jerlov 1968). The mean and SD of $k$ for each site were calculated across all the casts along the sampling transect at each site, as well as the mean and SD across all sites.

Macroalgal surveys. Benthic surveys were conducted from 2003 to 2005 to measure macroalgal distributions and abundance at 30 to $80 \mathrm{~m}$ depths. We used a combination of transect surveys with a remotely operated vehicle (Deep Ocean Engineering Phantom S2 ROV) enabling coverage of relatively large areas within and among sites, and mixed-gas decompression SCUBA diving allowing detailed sampling and collection at sites of significant algal abundance determined from the ROV surveys. ROV dives were conducted on the $30,40,50,60,70$, and $80 \mathrm{~m}$ isobaths seaward of each of the 4 study sites. During each ROV dive, 4 video transects of 5 to $10 \mathrm{~min}$ were run parallel to the depth contour with the ROV travelling approximately $1 \mathrm{~m}$ above the bottom. A digital imaging video camera was focused downwards approximately $1 \mathrm{~m}$ from the bottom and held an approximately constant field of view with parallel visible laser points $10 \mathrm{~cm}$ apart projected on the seafloor for scale. After each transect, the ROV was raised from the bottom and moved forward for approximately 5 min before again descending and starting another transect. The ROV moving with the prevailing current typically traveled 1 to $2 \mathrm{~km}$ per dive.

The video collected from each ROV dive was reviewed for a qualitative assessment of the extent of coverage of the benthic communities. A total of 10 to 25 individual video image frames from each transect were then examined in detail. Images chosen haphazardly from each transect were screened for optimum focus and consistent $1 \mathrm{~m}$ distance from the bottom. Frames showing only sand were included in calculations of total percent coverage, but then additional frames that showed benthic flora were included for analysis of the algae. Total area within each image was estimated using the $10 \mathrm{~cm}$ laser dot scale. A randomized grid of 100 points was then overlaid on each image and percent cover of total algae and visible bare substratum (generally sand) was estimated by scoring each point intercept. Image processing was accomplished using NIH Image software.

SCUBA surveys were conducted on the 30 to $70 \mathrm{~m}$ isobaths seaward of EL and CR. At each site, $30 \mathrm{~m}$ transect tapes were run and quantitative digital still photographs were taken at regular (ca. $2 \mathrm{~m}$ ) intervals with a 4 megapixel camera (Nikon Coolpix 4500) in an underwater housing (Ikelite) mounted on a rigid aluminum framer with coverage of $0.25 \mathrm{~m}^{2}$ (Fig. 2). After each of the transect photographs was taken, all macroalgae within the quadrat were collected by hand. The algal samples were subsequently identified (following Hanisak \& Blair 1988 and Littler \& Littler 2002), sorted in the laboratory into taxonomic 
groups (to genus and species when possible) and dried at $60^{\circ} \mathrm{C}$ for a minimum of $24 \mathrm{~h}$ prior to determination of dry biomass. Additional algae were collected for species identification in the general area of the transects and subsequently preserved in $5 \%$ buffered formalin. The high resolution quadrat photographs combined with collections allowed determination of percent cover by algal species in many instances; data on algal cover categorized by broad taxonomic category (Chlorophyta, Rhodophyta, Phaeophyceae) were used for comparisons among depths and sites.

Data from the ROV and diver quadrat surveys (number of sites $=2$, number of depths $=5$ ) were analyzed separately using 2 -factor analysis of variance (ANOVA) with site and depth as fixed factors. Percent cover data were arcsin-squareroot transformed to stabilize variance. For the ROV data, the total macroalgal cover was analyzed. For the diver quadrat images, the cover of macroalgae by major taxonomic category as well as total macroalgal cover were analyzed in separate ANOVA tests. Levels within the site and depth factors were compared with the Tukey HSD post hoc test following ANOVA. Probability levels of 0.05 were used in all significance tests.
Algal recruitment. To determine whether algal recruitment differed among sites and depths, recruitment plates were deployed by divers in September 2004 at the 30 to $70 \mathrm{~m}$ depth sites seaward of EL and $\mathrm{CR}$ and re-sampled in June 2005. At each location, 10 round, $30 \mathrm{~cm}$ diameter concrete plates were placed at approximately $2 \mathrm{~m}$ intervals along the depth contour $(10$ plates $\times 5$ depths $\times 2$ sites $=$ 100 plates total). In June 2005, the plates were photographed in situ with the digital camera on the $0.25 \mathrm{~m}^{2}$ framer. The photographs of the plates were analyzed by overlaying a randomized grid of 100 points and identifying the taxonomic group of the attached organisms under each point. For the algal recruitment data, the cover of macroalgae by major taxonomic category as well as total macroalgal cover were analyzed in separate ANOVA tests on arc-sine transformed data. Levels within the site and depth factors were compared with the Tukey HSD post hoc test following ANOVA.

Substratum particle size. Particle sizes from the sediment surface at each site were determined from a combination of photographic analysis for large particles, shell fragments, and cobble $>7 \mathrm{~mm}$ in diameter, and from analysis of diver-collected scoop samples (approximately 0.5 l) at each transect survey location for small particles $<7 \mathrm{~mm}$. For the large particles, size/frequency measurements were made from 10 quadrat photographs taken at EL and CR at each transect depth, with each image containing between 12 and 191 particles $>1 \mathrm{~cm}$ in diameter. The mean size of the large particles was compared among depths using a separate 1 factor ANOVA for EL and CR with depth $(\mathrm{n}=5)$ as a fixed factor. The size fraction of particles $<7 \mathrm{~mm}$ diameter was estimated from close-up photographic images taken of 42 subsamples of the dried diver-collected scoop samples. These samples (predominantly carbonate sand grains of coral, shell and coralline algal fragments) were spread on a glass plate above a black background and photographed using a digital camera and macro lens. Grains >45 $\mu \mathrm{m}$ diameter in each image were identified and counted using NIH Image software. For each location, the size/frequency of $>45000$ grains were measured.
Fig. 2. (A) ROV photograph of benthos dominated by benthic macroalgae at $60 \mathrm{~m}$ depth at Elbow Reef study site in 2004. (B,C) Individual $0.25 \mathrm{~m}^{2}$ photoquadrats taken by divers at the same site 


\section{RESULTS}

\section{Temperature patterns}

The bottom temperature time series at 30 to $70 \mathrm{~m}$ depth from CR (Fig. 3) illustrate persistent variability at temporal scales from hours and days to seasons. Detailed analysis of these and similar near-bottom temperature records across all the study sites from 2003 to 2005 indicate that the dominant high frequency variability arises from internal waves at tidal and faster fre-
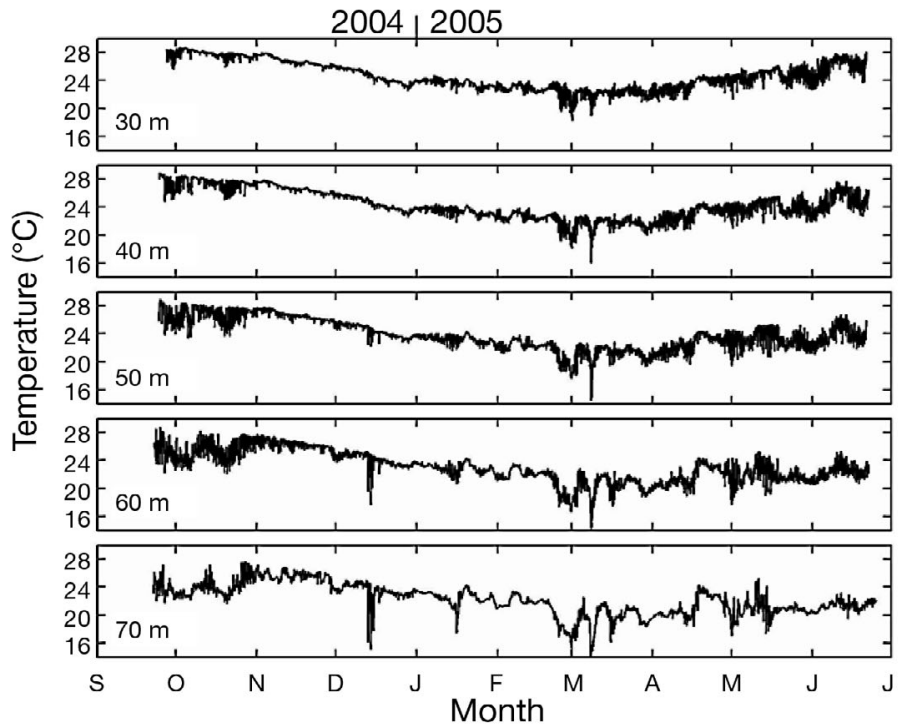

Oct 2004

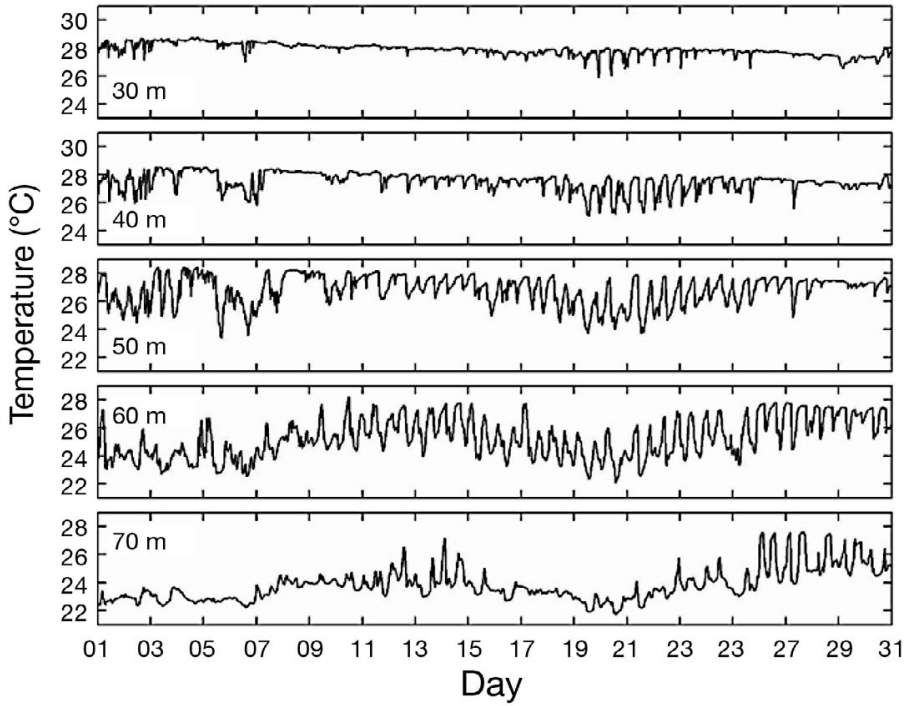

Fig. 3. Bottom temperature recorded at $20 \mathrm{~min}$ intervals at 30 , $40,50,60,70 \mathrm{~m}$ depth at Conch Reef from September 2004 to June 2005. Simultaneous data (not shown) were also collected at Elbow Reef and exhibit similar temperature variations. Top panels show full 9 mo record, lower panels show expanded viewfor variable period in October 2004 quencies and from the interaction of internal waves with reef topographic structure (Leichter et al. 1996, 2003 , 2005). The range of monthly mean temperatures was approximately $8^{\circ} \mathrm{C}$, while the overall temperature range was nearly double that, with a low of $15^{\circ} \mathrm{C}$ to highs close to $30^{\circ} \mathrm{C}$. This large range in temperatures reflects extensive, within-day variability. Although mean temperatures were coolest in winter months (January to March), large-scale cooling events were frequent in summer, for example in July, August and September 2004, when temperatures transiently dropped to as low as $16^{\circ} \mathrm{C}$.

In addition to differences in mean temperatures with depth, there were depth-specific patterns in the extent and duration of the exposure to cool water. At 30 and $40 \mathrm{~m}$ depth, the temperature variation was primarily composed of cooling events relative to a background warm level. At 50 and $60 \mathrm{~m}$, the temperature variation consisted of oscillations both upward and downward relative to the background, while at $70 \mathrm{~m}$ the background temperatures appeared generally cool with variation that consisted mostly of upward excursions to warmer temperatures. These patterns were consistent with the movement of water column thermal gradients associated with the thermocline past the fixed, bottommounted sensors.

Fig. 4 shows the average cooling degree hours per day at 30 to $70 \mathrm{~m}$ depth at EL and CR sites for September-October 2004 and May-June 2005. Exposure to cool, nutrient-rich water increased with increasing

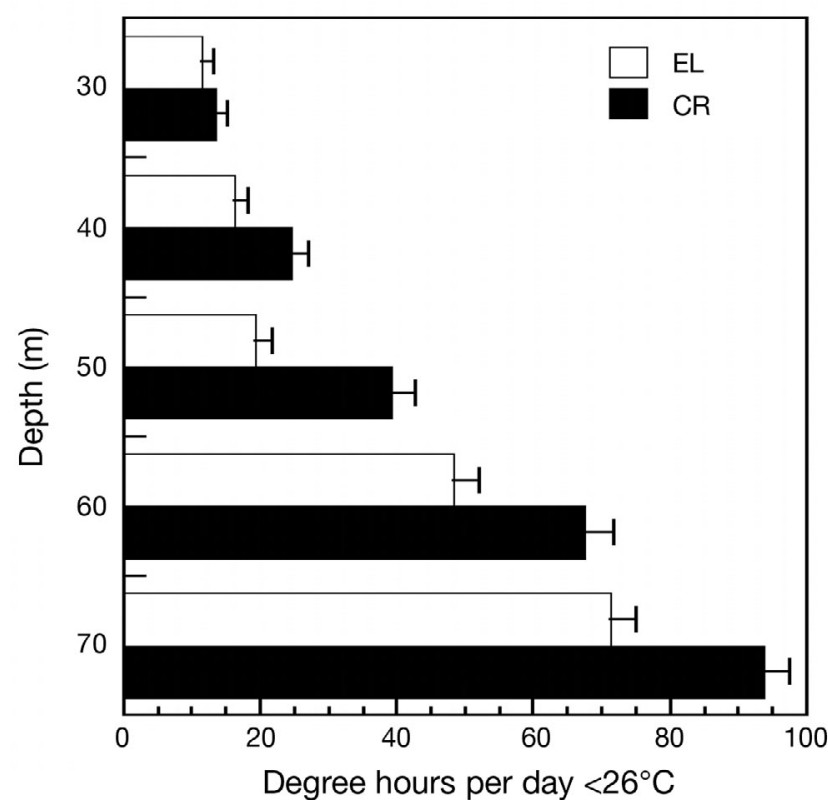

Fig. 4. Mean $+\mathrm{SE}$ degree hours $<26^{\circ} \mathrm{C}$ per day at 30 to $70 \mathrm{~m}$ depth for the sites at Elbow Reef (EL) and Conch Reef (CR) for the summer time periods September-October 2004 and May-June 2005 
depth, and also varied among sites at a given depth, with overall cooling greater at CR than at EL. The 2-factor ANOVA on these data showed significant effects of both Site $(F=52.12, \mathrm{df}=1, \mathrm{p}<0.001)$ and Depth $(F=170.78, \mathrm{df}=4, \mathrm{p}<0.001)$ and showed a significant Site $\times$ Depth interaction $(F=3.89, \mathrm{df}=4, \mathrm{p}=0.003)$. The direction of the depth effect (increasing degree cooling hours with increasing depth) was similar at both sites, and the direction of the site effect (greater cooling at CR than at EL) was consistent among depths. The significant Site $\times$ Depth interaction term occurred because the magnitude of the differences between CR and EL varied with depth (with less of a difference at $30 \mathrm{~m}$ ) and the difference among depths at EL was limited in the 30 to $50 \mathrm{~m}$ range (Fig. 4). Thus, we conclude that while cooling differs markedly across depths and between sites, differences among depths are not independent of site, and vice versa.

\section{Nutrients and irradiance}

TIN concentration varied from $0.05 \mu \mathrm{mol} \mathrm{l}^{-1}$ near the surface to $24.5 \mathrm{\mu mol} \mathrm{l}^{-1}$ at depth, corresponding to variation in temperatures ranging from 30.4 to $11.7^{\circ} \mathrm{C}$. Fig. 5 shows the relationship between TIN and temperature for the 75 water samples collected in September 2003. TIN concentration was tightly correlated with

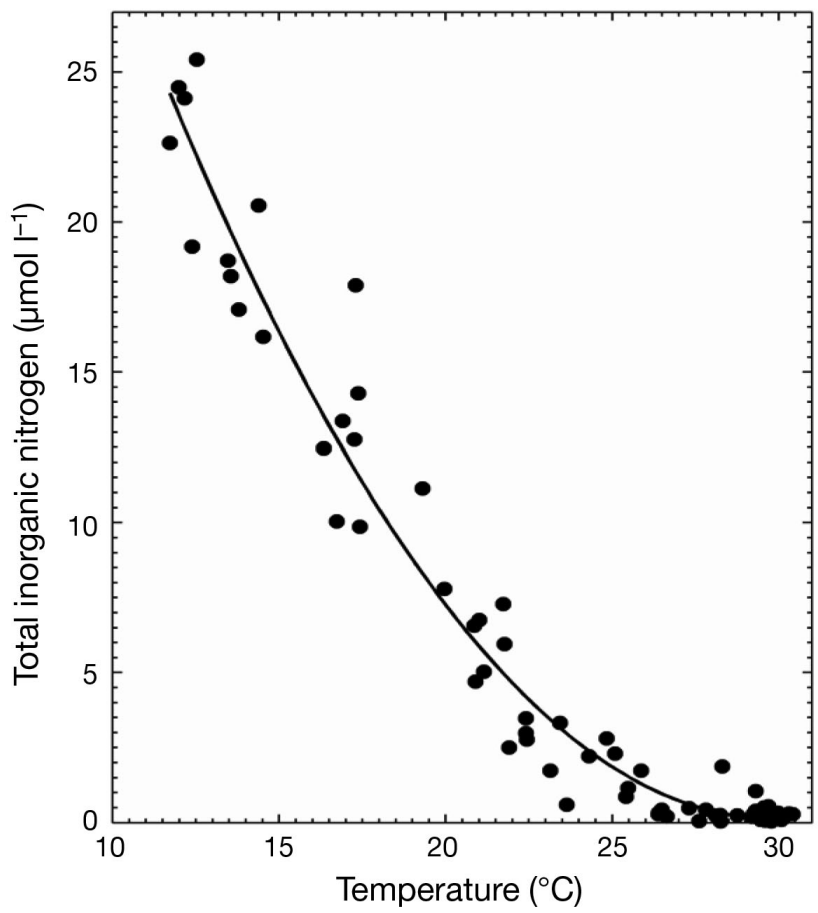

Fig. 5. Concentration of total inorganic nitrogen $\left(\mu \mathrm{mol} \mathrm{l}^{-1}\right)$ plotted against water temperature from hydrographic casts near the study sites. Solid line shows second order polynomial fit $y=-4.39 x+0.07 x^{2}+65.63, \mathrm{r}^{2}=0.98, \mathrm{n}=75$ temperature, with TIN increasing rapidly with decreasing temperature less than ca. $26.0^{\circ} \mathrm{C}$. In the range of temperatures from 20 to $25^{\circ} \mathrm{C}$, which included most of the cool temperatures observed in the bottom records, TIN concentration varied from approximately 0.5 to $8.0 \mu \mathrm{mol} \mathrm{^{-1 }}$. For temperatures between 16 and $18^{\circ} \mathrm{C}$, corresponding to the minimum temperatures observed at the benthic study sites, TIN was approxi-

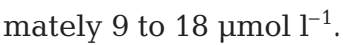

Photon irradiance from a representative cast at each of the sample sites is shown in Fig. 6. The mean \pm SD of the vertical light extinction coefficients, $k\left(\mathrm{~m}^{-1}\right)$, calculated for each site across all casts along the sampling transect were: EL $-0.046 \pm 0.008 ; \mathrm{CR}-0.067 \pm 0.008$; $\mathrm{LK}-0.052 \pm 0.009$; SK $-0.059 \pm 0.002$. Across all sites, mean \pm SD of $k$ was $-0.056 \pm 0.011$. These values are consistent with values typical of near-shore tropical Atlantic ocean waters (NATO 1973). Table 1 shows the predicted percent of surface irradiance at depth for a water column with a light extinction coefficient $k=$ $-0.06 \mathrm{~m}^{-1}$. The strong attenuation of light passing through even relatively clear waters results in strong depth gradients in light availability for benthic primary producers. For $k=-0.06 \mathrm{~m}^{-1}$ every $10 \mathrm{~m}$ increase in depth results in an additional $45 \%$ decrease in light availability. Thus, approximately $16 \%$ of surface PAR was present at $30 \mathrm{~m}$, decreasing to only $5 \%, 3 \%$, and $<2 \%$ of surface PAR at 50,60 , and $70 \mathrm{~m}$, respectively.

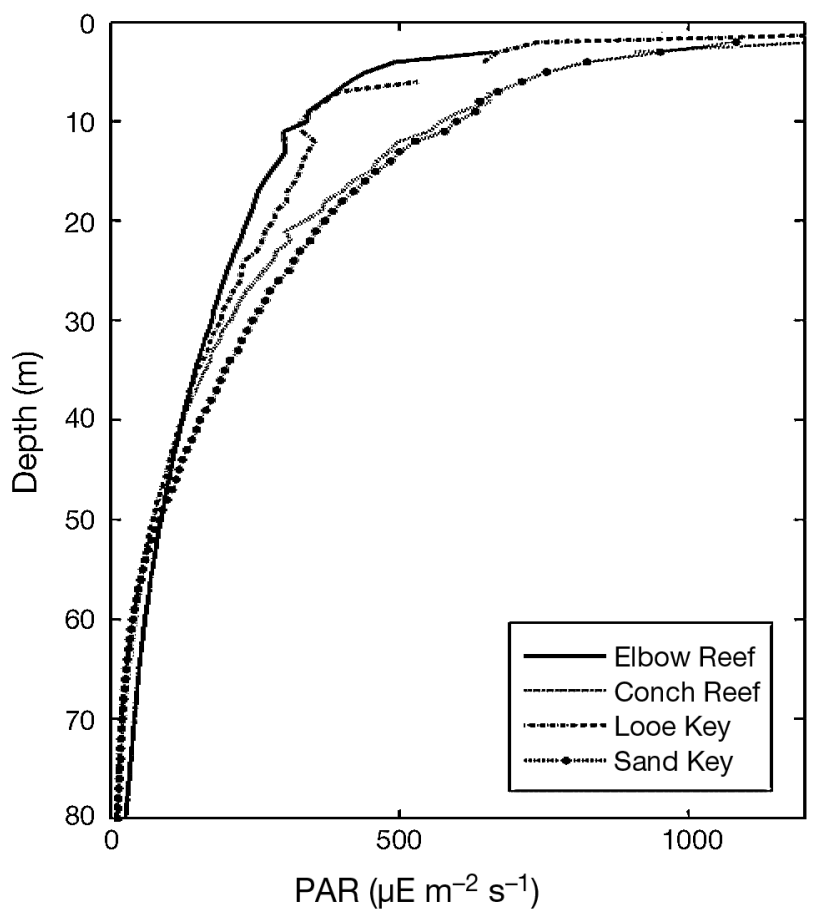

Fig. 6. Photon irradiance (PAR, $\mu$ mol photons $\mathrm{m}^{-2} \mathrm{~s}^{-1}$ ) as a function of depth (m) for a representative hydro-cast taken near the $80 \mathrm{~m}$ isobath seaward of each of the 4 main study sites. Site specific mean extinction coefficients provided in 'Results' 
Table 1. Calculated mean percent of surface irradiance at depth for water column with light extinction coefficient $-0.06 \mathrm{~m}^{-1}$

\begin{tabular}{|cc|}
\hline Depth $(\mathrm{m})$ & Percent surface irradiance \\
\hline 0 & 100.0 \\
10 & 54.9 \\
20 & 30.1 \\
30 & 16.5 \\
40 & 9.1 \\
50 & 5.0 \\
60 & 2.7 \\
70 & 1.5 \\
80 & 0.8 \\
90 & 0.5 \\
100 & 0.2 \\
\hline
\end{tabular}

\section{Macroalgal surveys}

The mean $( \pm \mathrm{SE})$ abundance of benthic macroalgae estimated from the ROV transects at the 4 main sites in June 2005 is shown in Fig. 1. Algal cover was $>80 \%$ in many areas and was highly variable among sites and depths. At sites of high macroalgal cover, such as EL 50 and $60 \mathrm{~m}$, the community was domi- nated by many species of Caulerpa, Halidmeda and other chlorophytes. Numerous bladed rhodophytes such as Halymenia floresia and Kallymenia spp. were present, with individual blades ranging from $10 \mathrm{~cm}$ to as much as $60 \mathrm{~cm}$ in length. A list of identified algal taxa is presented in Table 2. In general, algal cover was high at $40 \mathrm{~m}$ and deeper wherever hard substratum or partially consolidated substratum was present, with the exception of several areas where large aggregations of gorgonians (eg. Pseudopterogorgia spp., Pterogorgia spp., Plexaurella spp., Muricea sp.) were present and algal cover was lower than in adjacent areas without gorgonians.

Algal dry biomass ranged up to approximately $40 \mathrm{~g}$ $\mathrm{m}^{-2}$ for non-calcareous chlorophytes (and $68 \mathrm{~g} \mathrm{~m}^{-2}$ for Halimeda spp. including the calcareous material), $4 \mathrm{~g}$ $\mathrm{m}^{-2}$ for rhodophytes, and $2 \mathrm{~g} \mathrm{~m}^{-2}$ for Phaeophycaea. Algal cover estimates were relatively consistent within transects at a particular site and depth. At 3 of the 4 sites, the percent cover increased with depth and distance seaward from the base of the reefs. Seaward of EL and CR, algal cover was greatest at 40 to $60 \mathrm{~m}$, and decreased at 70 and $80 \mathrm{~m}$. Seaward of SK, algal cover was nearly $80 \%$ at $30 \mathrm{~m}$ and decreased with increasing depth. Algal cover seaward of LK was only 10 to $20 \%$

Table 2. Dominant benthic macroalgal species identified from transects between 30 and 70 m depth seaward of the Florida Keys reef tract. Depth $(\mathrm{m})$ of primary occurrence provided in parentheses

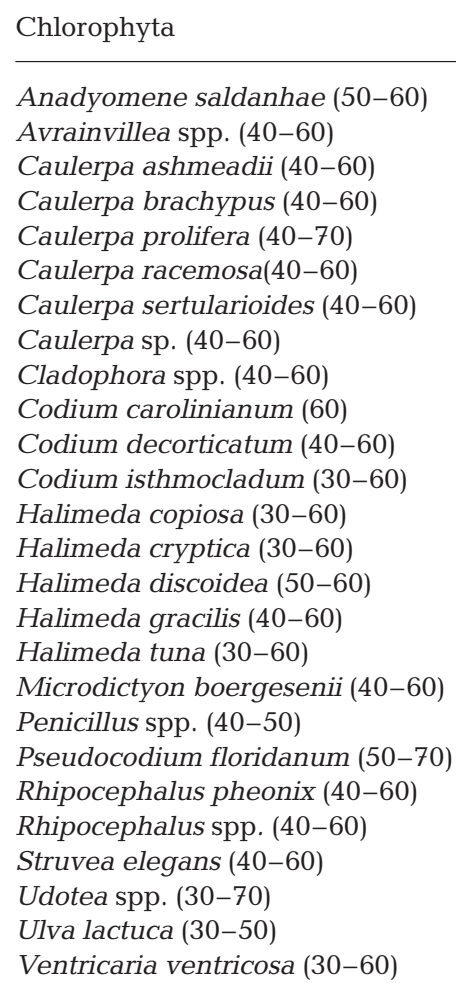

\section{Rhodophyta}

Agardhiella ramosissima (40-60)

Asparagopsis taxiformis (40-60)

Botryocladia pyriformis (40-60)

Ceramium spp. (40-60)

Chondria spp. (30-60)

Chrysymenia enteromorpha (40-60)

Dasya spp. (40-60)

Galaxaura obtusata (40-60)

Gracilaria spp. (30-60)

Grateloupia gibbesii (40-60)

Halymenia echinophysa (40-60)

Halymenia floresia (40-60)

Halymenia sp. (40-60)

Hypoglossum hypoglossoides (40-60)

Hypoglossum tenuifolium (40-60)

Kallymenia westii (40-60)

Kallymenia spp. (40-60)

Laurencia cervicornis (40-60)

Laurencia condrioides (40-60)

Polysiphonia spp. (40-70)

Rhodymenia sp. (30-60)

Scinaia sp. (30-70)

Sebdenia flabellata (30-70)
Phaeophyceae

Dictyopteris plagiogramma (30-50)

Dictyopteris sp. (30-50)

Dictyota menstrualis (30-60)

Dictyota spp. (30-60)

Lobophora variegata (30-60)

Padina spp. (30-60)

Sargassum hystrix (30-40)

Sargassum sp. (30-50)

Stypopodium zonale (30-40) 
Table 4. Results of significance tests ( $\mathrm{p}$ values) from 2 factor (site $\mathrm{n}=2$, depth $n=5)$ ANOVA on algal percent cover data from Conch Reef $(\mathrm{CR})$ and Elbow Reef (EL) classified by algal taxonomic category and total algae. Tukey HSD post hoc results show ranking of the 2 sites and grouping of 5 depths. Depths not connected by same letter are significantly different within each taxonomic grouping. Letter groups are organized in alphabetical order of mean cover $(\mathrm{A}=$ most cover)

\begin{tabular}{|lcccc|}
\hline Effect & Chlorophyta & Rhodophyta & Phaeophyceae & Total algae \\
\hline Site & $<0.0001$ & 0.1543 & $<0.0001$ & $<0.0001$ \\
Depth & $<0.0001$ & 0.0021 & $<0.0001$ & $<0.0001$ \\
Site $\times$ Depth & $<0.0001$ & $<0.0001$ & $<0.0001$ & $<0.0001$ \\
& & & & \\
Tukey HSD & & & & \\
Site: & EL $>$ CR & NA & CR $>$ EL & EL $>$ CR \\
Depth: & $30(\mathbf{A})$ & $30(\mathbf{A})$ & $30(\mathbf{A})$ & $30(\mathbf{A})$ \\
& $40(\mathbf{B})$ & $40(\mathbf{B})$ & $40(\mathbf{B})$ & $40(\mathbf{B})$ \\
& $50(\mathbf{A})$ & $50(\mathbf{A})$ & $50(\mathbf{A})$ & $50(\mathbf{A B})$ \\
& $60(\mathbf{A})$ & $60(\mathbf{A B})$ & $60(\mathbf{A})$ & $60(\mathbf{B})$ \\
& $70(\mathbf{B})$ & $70(\mathbf{A})$ & $70(\mathbf{A})$ & $70(\mathbf{C})$ \\
\hline
\end{tabular}

that at $30 \mathrm{~m}$ for all higher taxonomic categories and differed from 50 and $60 \mathrm{~m}$ for most. Algal cover at $70 \mathrm{~m}$ depth was significantly different from all other depths for total algae. As with the ROV survey data, the effect of depth varied with site resulting in a significant interaction effect. Specifically, at the $40 \mathrm{~m}$ site seaward of EL, there was extensive sand and low algal abundance (sand cover accounted for the vast majority of space not occupied by algae), whereas at the same depth at CR there was limited sand and high algal cover. At all sites, the deepest diver surveys at $70 \mathrm{~m}$ showed extensive sand. The macroalgae that were present at the $70 \mathrm{~m}$ sites tended to be rhizophytic species such as Caulerpa prolifera capable of growth in shifting sand.

\section{Algal recruitment}

Examples of the recruitment and growth of macroalgae on the artificial settlement substrata are shown in
Fig. 8 which shows one representative settlement block per depth for depths of 30, 40, 50, 60, and $70 \mathrm{~m}$ (left to right) from EL. These photographs illustrate the general pattern of low recruitment/ growth at $30 \mathrm{~m}$ close to the base of the reefs, increasing recruitment/growth at 50 and $60 \mathrm{~m}$, with subsequent reduction at $70 \mathrm{~m}$. At both EL and CR, several of the blocks at $70 \mathrm{~m}$ were covered by shifting sand. Patterns of algal recruitment/growth separated into broad taxonomic groups across all of the recruitment blocks are shown in Fig. 9. Results of the significance test of the ANOVA and the post hoc test on the algal recruitment data are shown in Table 5. Recruitment of chlorophytes was significantly greater at CR than at EL, while Phaeophyceae recruitment was significantly higher at EL than at CR. Recruitment of rhodophytes and total algae did not differ significantly among sites. The patterns among depths were mostly consistent across higher taxonomic categories, with the highest recruitment at 50 and $60 \mathrm{~m}$. The effect of depth varied with site resulting in a significant interaction effect (evident in Fig. 9). Specifically, the differences between 30-40 m and 50-60 m was larger at EL than at CR. Thus, while Site and Depth are not independent factors with respect to algal recruitment, significant differences were evident especially across depths. Relationships between the siteand depth-specific percent cover of benthic macroalgae on natural substrata measured in the diver photoquadrats and the algal cover on the recruitment blocks at the end of the 9 mo recruitment experiment are shown in Fig. 10. There was an apparent trend toward greatest macroalgal recruitment at locations with greatest benthic cover, most notably at 50 and $60 \mathrm{~m}$ at EL. However, macroalgal recruitment to the artificial settlement blocks did occur even in areas with rela-
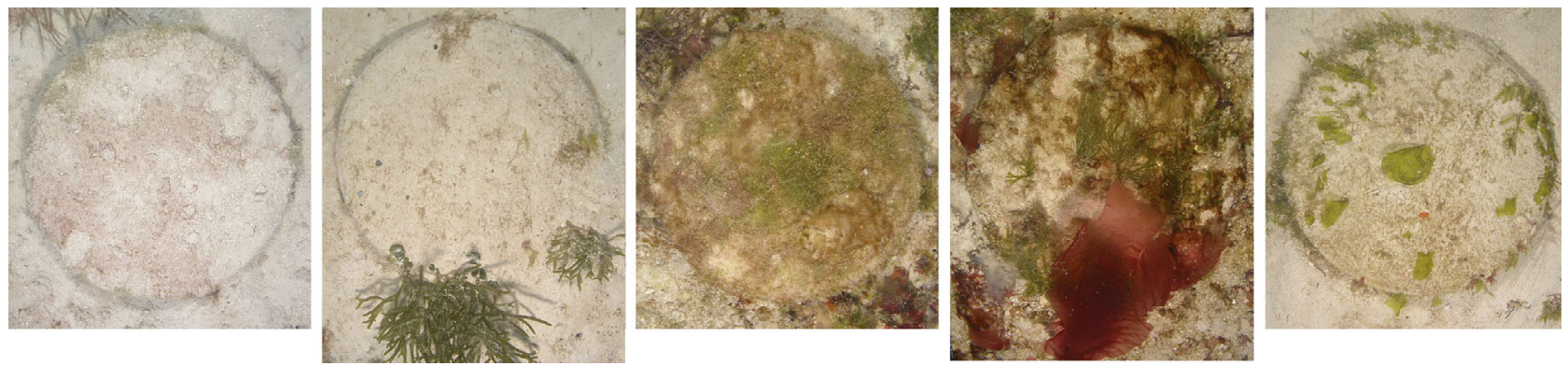

Fig. 8. $30 \mathrm{~cm}$ diameter algal recruitment blocks after 9 mo of recruitment and growth. Panels from left to right show one representative recruitment block from 30,40,50,60, and 70 m depth respectively from Elbow Reef 
tively low benthic macroalgal cover. Thus overall correlation between the depth-specific percent cover on the macroalgal recruitment blocks and benthic macroalgal cover was non-significant (Fig. 10).

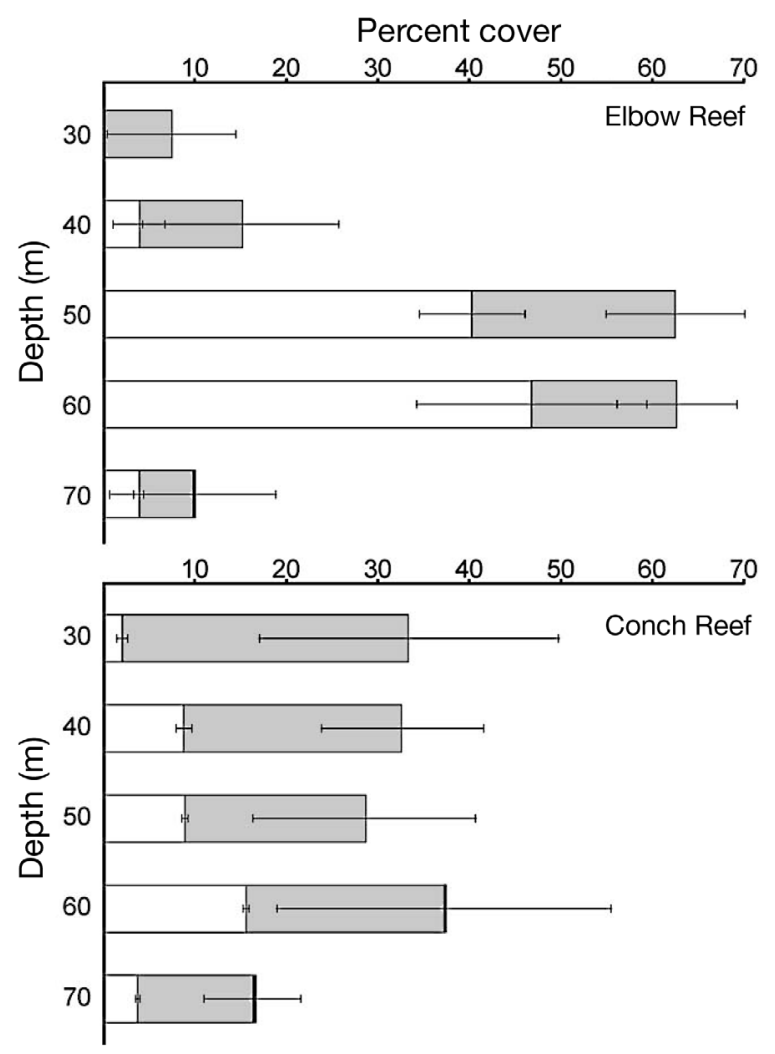

Fig. 9. Mean \pm SE percent cover of Chlorophyta (grey), Rhodophyta (black), and Phaeophyceae (white) estimated from image analysis of algal recruitment blocks photographed in June 2005 after 9 mo recruitment and growth experiment at Elbow Reef and Conch Reef

Table 5. Results of significance tests ( $p$ values) from 2 factor (site $n=2$, depth $n=5$ ) ANOVA on algal percent cover data from recruitment blocks deployed at Conch Reef (CR) and Elbow Reef (ER) classified by algal taxonomic category and total algae. Tukey HSD post hoc results show ranking of the 2 sites and grouping of 5 depths. Depths not connected by same letter are significantly different within each taxonomic grouping. Letter groups are organized in alphabetical order of mean cover $(\mathrm{A}=$ most cover $)$

\begin{tabular}{|lcccr|}
\hline Effect & Chlorophyta & Rhodophyta & Phaeophyceae & Total algae \\
\hline Site & $<0.0001$ & 0.0614 & $<0.0001$ & 0.7625 \\
Depth & $<0.004$ & 0.0073 & $<0.0001$ & $<0.0001$ \\
Site $\times$ Depth & $<0.0003$ & 0.0614 & $<0.0001$ & $<0.0001$ \\
& & & & \\
Tukey HSD & & & & \\
Site: & CR $>$ EL & NS & EL $>$ CR & NS \\
Depth: & $30(\mathbf{A B})$ & $40(\mathbf{A B})$ & $40(\mathbf{B})$ & $30(\mathbf{B})$ \\
& $40(\mathbf{A B})$ & $50(\mathbf{B})$ & $50(\mathbf{A})$ & $50(\mathbf{B})$ \\
& $50(\mathbf{A})$ & $60(\mathbf{A B})$ & $60(\mathbf{A})$ & $60(\mathbf{A})$ \\
& $60(\mathbf{A})$ & $70(\mathbf{A})$ & $70(\mathbf{B})$ & $70(\mathbf{B})$ \\
\hline
\end{tabular}

\section{Substratum particle size}

The diver-collected sediment samples indicated a substratum dominated by fine grained carbonate sand of a similar size and composition at all the study sites. The mean $( \pm \mathrm{SE})$ grain diameter of the small size fraction ( $<7 \mathrm{~mm}$ diameter) was $0.2 \mathrm{~mm} \pm 24.1 \mu \mathrm{m}$ for $>400000$ grains, with no significant difference in mean particle diameters between collection locations. For the larger size fraction ( $>7 \mathrm{~mm}$ diameter), there were significant differences in particle diameter between the sample locations (Table 6). At both EL and CR, the 60 and $70 \mathrm{~m}$ samples had smaller diameter substratum particles than those from shallower depths. These larger grains were typically composed of Halimeda and coral fragments presumably transported down slope from the fore reef.

\section{DISCUSSION}

The extensive, deep water macroalgal beds reported here represent a significant, previously unrecognized zone of primary production adjacent to the Florida Keys reef tract. The broad-scale ROV surveys and the more detailed diver sampling revealed dense macroalgal communities along a swath one to several $\mathrm{km}$ wide, with maximum abundance at depths of 50 to $60 \mathrm{~m}$, typically 0.5 to $2 \mathrm{~km}$ seaward of the reef tract. This swath, which we observed along the entire length of the FLKRT (ca. $200 \mathrm{~km}$ ) represents an area of many hundreds of square kilometers. To our knowledge, this is the first detailed report of the extensive macroalgal beds offshore in this location. In general, the ecology of deep water macroalgal communities is poorly understood. Previous investigations focusing on distributions of tropical macroalgal taxa at approximately 30 to $100 \mathrm{~m}$ depth have been made via submersible dives on the Florida Shelf in the vicinity of Ft. Lauderdale (Hanisak \& Blair 1988), and with SCUBA surveys at 25 to $60 \mathrm{~m}$ depth in the Florida Middle Grounds in the eastern Gulf of Mexico (Cheney \& Dyer 1974), as well as San Salvadore Island in the Bahamas (Littler et al. 1986), at a variety of sites around the Caribbean (Littler \& Littler 2000), and the Hawaiian Islands (Smith et al. 2005, H. Spalding unpubl. data). Deep water macroalgal communities are also known from the Mediterranean (e.g. Drew 1969, Ballesteros 1991, Ballesteros et al. 1998) and from cold 


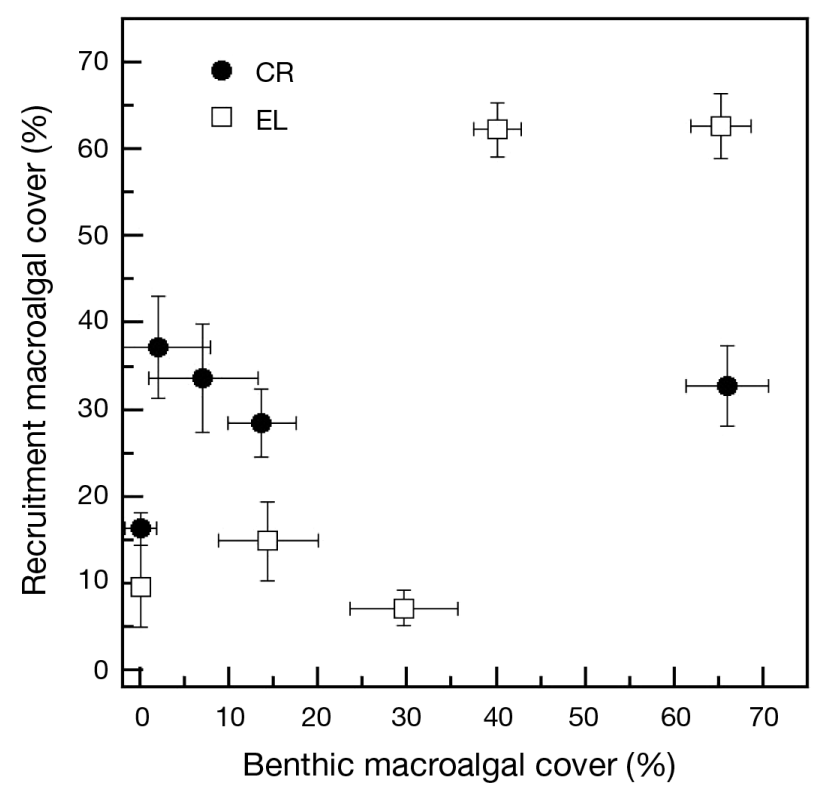

Fig. 10. Relationship at Conch Reef (CR) and Elbow Reef (EL) between total percent cover of macroalgae on natural substrata measured in benthic quadrat photographs and total percent cover of macroalgae on recruitment blocks after 9 mo of recruitment and growth. Points represent the means $\pm \mathrm{SE}$ for measurements at $30,40,50,60$, and $70 \mathrm{~m}$ depths at both sites. Overall coefficient of determination $r^{2}=0.33, p=0.08$

Table 6. Substratum particle size (mean diameter and SE) for large particles $(>7.0 \mathrm{~mm})$ as a function of depth seaward of Conch Reef and Elbow Reef, June 2005. Particle sizes analyzed from 10 photoquadrats per depth with each image containing between 12 and 191 particles. Single factor analysis of variance indicates differences in mean particle diameter between depths, $\mathrm{p}<0.05$. Depths that differ significantly $(\mathrm{p}<$ 0.05 ) by Tukey HSD post hoc test are indicated by different letter groups, organized in alphabetical order of particle size, $(\mathrm{A}=$ largest). NA (not available) indicates depths where no substratum particles $>7 \mathrm{~mm}$ were visible in the photoquadrats

\begin{tabular}{|lcccc|}
\hline Site & $\begin{array}{c}\text { Depth } \\
(\mathrm{m})\end{array}$ & \multicolumn{2}{c|}{ Particle size $(\mathrm{mm})$} & $\mathrm{p}<0.05$ \\
& Mean & SE & \\
\hline Conch Reef & 30 & 19.2 & 0.8 & $\mathbf{A}$ \\
& 40 & 22.0 & 4.9 & $\mathbf{A}$ \\
& 50 & 20.4 & 1.5 & $\mathbf{A}$ \\
& 60 & 16.0 & 2.1 & $\mathbf{B}$ \\
& 70 & NA & NA & \\
Elbow Reef & 30 & 26.9 & 2.0 & A \\
& 40 & NA & & \\
& 50 & 33.9 & 1.8 & A \\
& 60 & 18.5 & 0.7 & B \\
& 70 & 8.4 & 0.6 & $\mathbf{C}$ \\
\hline
\end{tabular}

water habitats, for example off the California coast (Spalding et al. 2003). While macroalgal growth rates in deep water FLKRT communities remain to be determined, carbon fixation may be quite significant relative to that on the reef tract. The macroalgal beds may serve an important role in the life cycles of reef-associated fish and invertebrates, and the transport of macroalgal fragments may be a source of carbon for grazers on the reef tract.

Both the extent and abundance of macroalgal beds in this system were unexpected. Our previous observations at 30 to $35 \mathrm{~m}$ depth within approximately $50 \mathrm{~m}$ of the reef tract showed a mostly bare substratum of carbonate particles and sand with occasional, scattered macroalgae. However, the physical data identify ample supplies of nutrients and adequate light for primary production, and these patterns are borne out by the abundance of macroalgae in deeper water.

In Florida, Cheney \& Dyer (1974) and Hanisak \& Blair (1988) described the presence of both annual and perennial species, and seasonal variation in species richness, with the greatest number of species found in summer and somewhat lower species richness in winter. This seasonality was hypothesized to be a result of variation in disturbance associated with winter storms, and also could result from some species with multistage life cycles existing only as inconspicuous benthic crusts during parts of the year. Cheney \& Dyer (1974) also proposed that cool winter temperatures might be suboptimal for certain taxa of tropical macroalgae. For the Florida Keys sites, we see clear seasonal cycles in physical variables such as temperature (Fig. 7; see also Leichter et al. 1996, 2003), as well as extensive higher frequency variation associated with bouts of cooling in the summer months during which within-day temperatures can be significantly lower than the minimum winter temperatures. Because our dive sampling was restricted to summer months, we cannot assess the seasonal persistence of the offshore macrophyte community. However, we consistently observed these communities at the same locations over 3 successive summers. The sampling in 2005 followed several significant hurricanes that had impacted the Florida Keys, yet the deep algal communities appeared to be undisturbed. At depths greater than 30 to $40 \mathrm{~m}$ these communities are likely to be reasonably protected from most physical effects such as storm-induced wave and current motion.

The general factors likely to control the distribution and structure of the macroalgal communities seaward of the FLKRT are the availability of suitable substratum, light, and nutrients, as well as physical and biological disturbance. The broad scale surveys clearly indicate an overriding effect of substratum availability on the distribution of the macroalgal communities. Specifically, macroalgae were essentially absent from areas of extensive sand which had migrating sand waves and ripples suggesting sand thickness of $\geq 10 \mathrm{~cm}$. At all of the sites, the deep margin of the macroalgal distribution coincided with the presence of 
extensive sand deposits at 70 to $80 \mathrm{~m}$. Additionally, the sites with the highest overall cover of sand (LK, and deep regions seaward of the aptly-named Sand Key, SK) had the lowest macroalgal cover. Conversely, at sites such as EL 50 and $60 \mathrm{~m}$, the presence of abundant macroalgae corresponded to large areas of partially consolidated substratum, coral and shell fragments and much more limited fine sand deposits. Thus, substratum availability is clearly a dominant factor in controlling the algal distributions, as has been consistently observed in other macroalgal communities in cool temperate regions (Graham et al. 2003, Smith et al. 2005). It is also possible that the presence of attached macroalgae serves to stabilize the substratum and reduce sand inundation.

While the lower depth distribution of macroalgae in this system corresponds with a shift in substratum availability associated with areas of extensive sand, reduced light availability at depth must also be considered as a potential contributing factor. The light data show that on average $<1 \%$ of surface irradiance is available below 70 to $80 \mathrm{~m}$ depth. Light levels of $0.7 \%$ of surface irradiance correspond to the lower limit of distribution of kelps, while levels of 0.05 to $0.1 \%$ of surface irradiance is a likely lower limit for multicellular algae (Lüning \& Dring 1979, Lobban \& Harrison 1994). In addition, many of the taxa such as Anadyomonene, Codium, Halimeda, Lobophora, Galaxauria, and Halymenia that we have found at 60 and $70 \mathrm{~m}$ depth have been collected from deeper water $(>90 \mathrm{~m}$ ) in other regions (Littler \& Littler 2000). Thus, light alone may not be the sole determinant of the lower depth limit of distribution for the algal communities observed in this study.

The frequency and cumulative duration of exposure to cool, subthermocline water masses as well as the abundance and robust condition of macroalgae collected at 40 to $70 \mathrm{~m}$ depth point to an ample supply of nutrients reaching the benthic communities seaward of the FLKRT. Temperatures below approximately $26^{\circ} \mathrm{C}$ correspond to water masses at or below the thermocline and the concentrations of both nitrate and phosphate increased nearly linearly with decreasing temperature (data shown here, and in Leichter et al. 2003, 2007). The data from 30 to $70 \mathrm{~m}$ depth show increasing exposure to low temperatures with increasing depth and suggest that the main thermocline was often at approximately 50 to $60 \mathrm{~m}$ depth, with frequent incursions into shallower depths. In addition, many of the large rhodophytes exhibited dense reproductive structures along their blades during the summer sampling (authors' pers. obs.) again suggesting ample nutrient availability and potentially rapid growth rates. A valuable, although logistically challenging, next step toward understanding the dynamics of this system would be to measure macroalgal photosynthetic and growth rates in situ.

The extensive degree of nutrient forcing via the advection of deep water to shallower depths along the Florida Keys (Leichter et al. 2003, Smith et al. 2004) and recent observations that the taxa we found at 50 to $60 \mathrm{~m}$ depth can grow in fish exclusion cages at 15 to $20 \mathrm{~m}$ depth on the reef slopes (M. Hay pers. comm.) suggest neither nutrient limitation nor photoinhibition of macroalgae controls the upper depth distribution of macroalgae in this system. While the present study did not directly measure the effects of herbivory, our observations and other studies allow us to hypothesize that the upper depth distribution of these macroalgal communities at 30 to $40 \mathrm{~m}$ depth reflects the role of herbivory, particularly by reef-associated grazing fishes. Taxonomic descriptions from broad field sampling in the Atlantic and Caribbean (Littler \& Littler 2000) show that many of the dominant species we find at 40 to $60 \mathrm{~m}$ along the FLKRT can exist in the shallower waters of other locations. In addition, we have observed areas of reduced algal abundance within 10 to $20 \mathrm{~m}$ around Florida wrecks at 50 to $60 \mathrm{~m}$ depth that suggest grazing by herbivorous fish living within the cover provided by the wreck structure (authors' pers. obs.). Grazing halos within seagrass beds are thought to play a role in fish recruitment patterns (Sweatman \& Robertson 1994). In shallower water, at 30 to $35 \mathrm{~m}$ depth at the base of the reef slopes, we have also observed areas of reduced algal abundance in a band approximately 30 to $50 \mathrm{~m}$ from the reef base, as well as observations of some typical reef fish (e.g. Acanthurids, Pomacanthids) grazing within this zone.

Further evidence for the potential role of herbivory influencing the shallow distribution of the macroalgal communities is suggested by the distribution of functional types of macroalgae (sensu Littler et al. 1983, Steneck \& Dethier 1994) observed in this system. As Steneck \& Dethier (1994) have shown for many macroalgal communities, with increasing herbivore pressure a shift can be observed from relatively consumable foliose and corticated algal forms such as Ulva spp. to branching and leathery forms such as Sargassum spp. that are more resistant to grazing. The presence of chemically defended species is similarly known to increase with increasing herbivore pressure (Hay 1983). In our surveys, at the sites of highest macroalgal abundance (50 to $60 \mathrm{~m}$ depth and approximately 1.0 to $1.5 \mathrm{~km}$ from the reef tract) we found a mix of species including numerous red foliose large bladed forms such as Halymenia floresia and Kallymenia spp. We also observed several events in which fragments of these species were transported by onshore current to near the base of the fore reef tract at $30 \mathrm{~m}$ depth and were then rapidly consumed by grazing acanthurids 
such as the French angelfish Pomacanthus paru (authors' pers. obs.). Thus, the macroalgae that are abundant in deeper water may be easy targets for fish grazing when they are found closer to the bases of the reefs. Direct measurements of grazing pressure as a function of distance from reef structure could offer insight into the ability of grazers to influence the distribution of deep water macroalge in this system.

The observed patterns of algal recruitment support the potential role of depth-dependent herbivory in structuring the upper distribution of the macroalgal communities. Specifically, we hypothesize that the reduced recruitment of algae on the algal recruitment plates placed at $30 \mathrm{~m}$ at both EL and CR was a direct effect of fish grazing near the base of the reefs. Additionally, the recruitment measurements point to the inhibiting effect of disturbance associated with sand inundation in deeper water. We hypothesize that the reduced recruitment at $70 \mathrm{~m}$ relative to 50 and $60 \mathrm{~m}$ reflects both sand burial and potentially reduced light availability. At $70 \mathrm{~m}$ depth at both EL and CR, sand movement was sufficient to bury 3 and 4 of the 10 recruitment plates, respectively.

In summary, in addition to revealing the high abundance of macroalgae and large areas with potentially for high primary productivity, the present data allow us to construct hypotheses regarding major factors structuring these benthic communities. The availability of ample supplies of nutrients associated with cool water exposure in this system is arguably the most important single factor supporting the deep water macroalgal communities. In the absence of persistent nutrient supply these communities might not exist or might exhibit altered community structure and reduced biomass. Additional studies in other locations could be extremely valuable toward understanding the prevalence of deep macroalgal communities throughout the tropics and in relation to local nutrient exposure. Given the abundant nutrient supply in this system, it is likely that factors including substratum, light availability and grazing interact to set the distribution of the macroalgal communities. At scales of 100 s of meters to kilometers, the overall patchiness of the benthic communities appears strongly tied to substratum availability and the movement of shifting sands. The lower distributional limits of the community are likely set by the presence of extensive sand but may also be influenced by reduced light availability. We hypothesize that the upper distribution limit is driven by herbivory from reef associated grazers. Export of fixed carbon from the deep macroalgal communities in the form of algal fragments and detritus appears to be rapidly consumed when transported to the reef slopes. Although Passarge et al. (2006) demonstrated a lack of trade-offs between competitive abilities for nutrients (phos- phorus) and light in 5 species of phytoplankton grown in laboratory chemostats, the more complex macroalgal-dominated ecosystem seaward of the Florida Keys could provide an interesting natural setting in which to test competition theories (Tilman 1982) among primary producers across gradients of nutrient and light availability.

Acknowledgements. We thank the entire staff of the National Undersea Research Center, Key Largo, FL for logistic support. We especially thank D. Kesling, L. Horn, J. Styron, and G. Taylor for training and tireless support of technical diving and ROV operations. Additional support for ROV operations and multiple uses of the RV 'Odyssey' was kindly provided by the National Marine Sanctuary, Key Largo. We also thank the entire crew of the RV 'Walton-Smith' and the Marine Operations Department at University of Miami RSMAS. We thank divers L. Kintzing, C. McDonald, M. Murray, O. Rutten, and W. Peterson for assistance with technical diving. D. Hanisak and S. Miller provided assistance with algal identification and along with J. Smith provided valuable discussion. R. Jones provided nutrient analysis. Three anonymous reviewers provided valuable comments. Funding was provided by grants from the National Undersea Research Center, University of North Carolina at Wilmington, and the National Science Foundation (OCE-998654)

\section{LITERATURE CITED}

Andrews JC, Gentien P (1982) Upwelling as a source of nutrients for the Great Barrier Reef ecosystems: a solution to Darwin's question? Mar Ecol Prog Ser 8:257-269

Atkinson MJ, Bilger RW (1992) Effects of water velocity on phosphate uptake in coral reef-flat communities. Limnol Oceanogr 37:273-279

Bak RP, Nieuwland G, Meesters EH (2005) Coral reef crisis in deep and shallow reefs: 30 years of constancy and change in reefs of Curaçao and Bonaire. Coral Reefs 24:475-479

Ballesteros E (1991) Seasonality of growth and production of a deep-water population of Halimeda tuna (Chlorophyceae, Caulerpales) in the north-western Mediterranean. Bot Mar 34:291-301

Ballesteros E, Sala E, Garrabou J, Zabala M (1998) Community structure and frond size distribution of a deep water stand of Cystoseira spinosa (Phaeophyta) in the northwestern Mediterranean. Eur J Phycol 33:121-128

Bell PRF (1992) Eutrophication and coral reefs: some examples in the Great Barrier Reef lagoon. Water Res 26:553-568

Boyer JN, Jones RD (2002) A view from the bridge: external and internal forces affecting the ambient water quality of the Florida Keys National Marine Sanctuary (FKNMS). In: Porter JW, Porter KG (eds) The Everglades, Florida Bay, and coral reefs of the Florida Keys. An ecosystem sourcebook. CRC Press, Boca Raton, FL, p 609-628

Bustamante RH, Branch GM, Eekhout S (1995) Maintenance of an exceptional intertidal grazer biomass in South Africa - subsidy by subtidal kelps. Ecology 76:2314-2329

Carpenter RC (1986) Partitioning herbivory and its effects on coral-reef algal communities. Ecol Monogr 56:345-363

Cheney DP, Dyer JP (1974) Deep-water benthic algae of Florida Middle Ground. Mar Biol 27:185-190

Colin PL (1996) Longevity of some coral reef fish spawning aggregations. Copeia 1996:189-192

D'Elia CF, Wiebe WJ (1990) Biogeochemical nutrient cycles in 
coral-reef ecosystems. In: Dubinsky Z (ed) Ecosystems of the world, Vol 25. Coral reefs. Elsevier, Amsterdam, p 49-74

Domeier ML, Colin PL (1997) Tropical reef fish spawning aggregations: defined and reviewed. Bull Mar Sci 60: 698-726

Done TJ (1992) Phase shifts in coral reef communities and their ecological significance. Hydrobiologia 247:121-132

Drew EA (1969) Photosynthesis and growth of attached marine algae down to 130 metres in the Mediterranean. Proc Int Seaweed Symp 6:151-159

Duggins DO, Simenstad CA, Estes JA (1989) Magnification of secondary production by kelp detritus in coastal marine ecosystems. Science 245:170-173

Edmunds PJ, Carpenter RC (2001) Recovery of Diadema antillarum reduces macroalgal cover and increases abundance of juvenile corals on a Caribbean reef. Proc Nat Acad Sci USA 98:5067-5071

Ellison AM, Farnsworth EJ (2001) Mangrove communities. In: Bertness MD, Gaines SD, Hay ME (eds) Marine community ecology. Sinauer Associates, Sunderland, MA, p 423-442

Graham MH, Dayton PK, Erlandson JM (2003) Ice ages and ecological transitions on temperate coasts. Trends Ecol Evol 18:33-40

Hanisak MD (2001) Macroalgal blooms in Florida's coastal waters: Codium isthmocladum. J Phycol 37 (Suppl 3):21

Hanisak MD, Blair SM (1988) The deep-water macroalgal community of the East Florida continental-shelf (USA). Helgol Meeresunters 42:133-163

Hanisak MD, Siemon LW (2000) Macroalgal tissue nutrients as indicators of nitrogen and phosphorus status in the Florida Keys. J Phycol 36 (Suppl 3):28

Hay ME (1983) Herbivory, algal distribution, and the maintenance of between-habitat diversity on a tropical fringing reef. Am Nat 118:520-540

Hughes T, Szmant AM, Steneck R, Carpenter R, Miller S (1999) Algal blooms on coral reefs: what are the causes? Limnol Oceanogr 44:1583-1586

Jerlov NG (1968) Optical oceanography. Elsevier, Amsterdam

Jompa J, McCook LJ (2002) The effects of nutrients and herbivory on competition between a hard coral (Porites cylindrica) and a brown alga (Lobophora variegata). Limnol Oceanogr 47:527-534

Knowlton N (2001) The future of coral reefs. Proc Nat Acad Sci USA 98:5419-5425

Kruczynski WL, McManus F (2002) Water quality concerns in the Florida Keys: sources, effects, and solutions. In: Porter JW, Porter KG (eds) The Everglades, Florida Bay, and coral reefs of the Florida Keys. An ecosystem sourcebook. CRC Press, Boca Raton, FL, p 827-881

Lapointe BE (1997) Nutrient thresholds for bottom-up control of macroalgal blooms on coral reefs in Jamaica and southeast Florida. Limnol Oceanogr 42:1119-1131

Lapointe BE (1999) Simultaneous top-down and bottom-up forces control macroalgal blooms on coral reefs - (Reply to the comment by Hughes et al.). Limnol Oceanogr 44:1586-1592

Lee TN, Mayer DA (1977) Low-frequency current variability and spin-off eddies along shelf off southeast Florida. J Mar Res 35:193-220

Lee TN, Schott FA, Zantopp R (1985) Florida Current - low-frequency variability as observed with moored current meters during April 1982 to June 1983. Science 227:298-302

Leichter JJ, Genovese SJ (2006) Intermittent upwelling and subsidized growth of the scleractinian coral Madracis mirabilis on the deep fore-reef slope of Discovery Bay, Jamaica. Mar Ecol Prog Ser 316:95-103
Leichter JJ, Wing SR, Miller SL, Denny MW (1996) Pulsed delivery of subthermocline water to Conch Reef (Florida Keys) by internal tidal bores. Limnol Oceanogr 41: 1490-1501

Leichter JJ, Shellenbarger G, Genovese SJ, Wing SR (1998) Breaking internal waves on a Florida (USA) coral reef: a plankton pump at work? Mar Ecol Prog Ser 166:83-97

Leichter JJ, Stewart HL, Miller SL (2003) Episodic nutrient transport to Florida coral reefs. Limnol Oceanogr 48: 1394-1407

Leichter JJ, Deane GB, Stokes MD (2005) Spatial and temporal variability of internal wave forcing on a coral reef. J Phys Oceanogr 35:1945-1962

Leichter JJ, Paytan AP, Wankel S, Hanson K, Miller SL (2007) Nitrogen and oxygen isotopic signatures of subsurface nitrate: evidence of deep water nutrient sources to the Florida Keys reef tract. Limnol Oceanogr 52: 1258-1267

Littler DS, Littler MM (2000) Caribbean reef plants. Offshore Graphics, Washington, DC

Littler MM, Littler DS (1984) Models of tropical reef biogenesis: the contribution of algae. Prog Phycol Res 3: 323-363

Littler MM, Littler DS, Taylor PR (1983) Evolutionary strategies in a tropical barrier reef system: functional-form groups of marine macroalgae. J Phycol 19:229-237

Littler MM, Littler DS, Blair SM, Norris JN (1986) Deep-water plant communities from an uncharted seamount off San Salvador Island, Bahamas: distribution, abundance, and primary productivity. Deep-Sea Res 33:881-892

Lobban CS, Harrison PJ (1994) Seaweed ecology and physiology. Cambridge University Press, New York

Lüning K, Dring MJ (1979) Continuous underwater light measurement near Helgoland (North-Sea) and its significance for characteristic light limits in the sublittoral region. Helgoländer wiss Meeresunters 32:403-424

McCook LJ (1999) Macroalgae, nutrients and phase shifts on coral reefs: scientific issues and management consequences for the Great Barrier Reef. Coral Reefs 18: 357-367

Mumby PJ, Edwards AJ, Arias-Gonzalez JE, Lindeman KC and 8 others (2004) Mangroves enhance the biomass of coral reef fish communities in the Caribbean. Nature 427: $533-536$

NATO (North Atlantic Treaty Organization) (1973) Optics of the sea: interface and in-water transmission and imaging. Advisory Group for Aerospace Research and Development. Electromagnetic Wave Propagation Panel. 1973. AGARD lecture series, no. 61. National Aeronautics and Space Administration, Washington, DC

Passarge J, Hol S, Escher M, Huisman J (2006) Competition for nutrients and light: stable coexistence, alternative stable states, or competitive exclusion? Ecol Monogr 76:57-72

Smith JE, Smith CM, Vroom PS, Beach KL, Miller S (2004) Nutrient and growth dynamics of Halimeda tuna on Conch Reef, Florida Keys: possible influence of internal tides on nutrient status and physiology. Limnol Oceanogr 49: 1923-1936

Smith JE, Runcie JW, Smith CM (2005) Characterization of a large-scale ephemeral bloom of the green alga Cladophora sericea on the coral reefs of West Maui, Hawai'i. Mar Ecol Prog Ser 302:77-91

Smith SV, Kimmerer WJ, Laws EA, Brock RE, Walsh TW (1981) Kaneohe Bay sewage diversion experiment: perspectives on ecosystem responses to nutritional perturbation. Pac Sci 35:279-385

Spalding H, Foster MS, Heine JN (2003) Composition, distrib- 
ution, and abundance of deep-water (> $30 \mathrm{~m}$ ) macroalgae in central California. J Phycol 39:273-284

Steneck RS, Dethier MN (1994) A functional-group approach to the structure of algal-dominated communities. Oikos 69: 476-498

Sweatman H, Robertson DR (1994) Grazing halos and predation on juvenile Caribbean surgeonfishes. Mar Ecol Prog Ser 111:1-6

Tilman D (1982) Resource competition and community structure. Princeton University Press, Princeton, NJ

Valiela I, Bowen JL, York JK (2001) Mangrove forests: one

Editorial responsibility: Matthias Seaman,

Oldendorf/Luhe, Germany of the world's threatened major tropical environments. BioScience 51:807-815

Vetter EW (1995) Detritus-based patches of high secondary production in the nearshore benthos. Mar Ecol Prog Ser 120:251-262

Vroom PS, Page KN, Kenyon JC, Brainard RE (2006) Algaedominated reefs. Am Sci 94:430-437

Williams SL, Heck KL Jr (2001) Seagrass community ecology. In: Bertness MD, Gaines SD, Hay ME (eds) Marine community ecology. Sinauer Associates, Sunderland, MA, p 317-337

Submitted: June 8, 2006; Accepted: August 24, 2007

Proofs received from author(s): March 3, 2008 